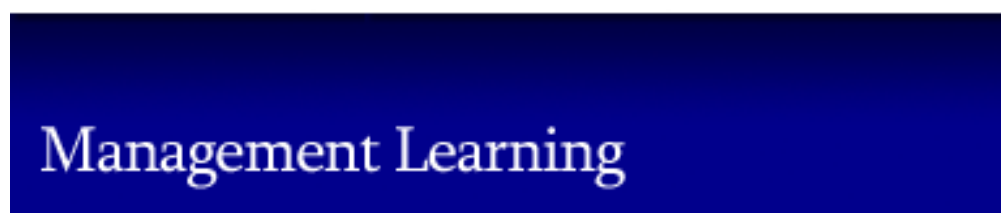

\title{
Imagining a Different Voice: a critical and caring approach to management education
}

\begin{tabular}{|c|c|}
\hline Journal: & Management Learning \\
\hline Manuscript ID & MLQ-17-0204.R2 \\
\hline Manuscript Type: & Original Article \\
\hline Keywords: & $\begin{array}{l}\text { Critical management education, Sustainability, Care ethics, } \\
\text { Transformative learning }\end{array}$ \\
\hline Abstract: & $\begin{array}{l}\text { This paper discusses the use of the moral philosophy known as the ethics } \\
\text { of care (Gilligan, 1982; Held, 2006) to critically engage management } \\
\text { students in ways that favour the development and enactment of a critical } \\
\text { and responsible mentality towards business. We use this ethics to } \\
\text { ground critical thinking in a moral framework in order to create a } \\
\text { conversation in which new possibilities for sustainable and ethical } \\
\text { practices might be discovered. Specifically, we identify four teaching } \\
\text { practices that allow students to experience being both 'cared for' and } \\
\text { 'one-caring' and explore how this creates a deeper and more critical } \\
\text { moral engagement with those affected by businesses. We further } \\
\text { propose a framework for applying a care-ethical approach for teaching } \\
\text { and learning. }\end{array}$ \\
\hline
\end{tabular}

\section{SCHOLARONE" Manuscripts}




\title{
Imagining a Different Voice: a critical and caring approach to management education
}

\begin{abstract}
This paper discusses the use of the moral philosophy known as the ethics of care (Gilligan, 1982; Held, 2006) to critically engage management students in ways that favour the development and enactment of a critical and responsible mentality towards business. We use this ethics to ground critical thinking in a moral framework in order to create a conversation in which new possibilities for sustainable and ethical practices might be discovered. Specifically, we identify four teaching practices that allow students to experience being both 'cared for' and 'one-caring' and explore how this creates a deeper and more critical moral engagement with those affected by businesses. We further propose a framework for applying a care-ethical approach for teaching and learning.
\end{abstract}

Keywords: Care Ethics, Transformative Learning, Sustainability, Critical Management Education 


\section{Introduction}

In this paper we challenge management discourse that normalises the primacy of profit over goodness and examine the potential of the moral theory called the ethics of care (Gilligan, 1982) to help students find an alternative voice. In so doing, we seek to facilitate the development of a caring and critical attitude towards business decisions among students, and contribute to a growing dialogue about transforming business education (Sinclair, 1997; Dehler, 2009; Vince, 2010; Śliwa, Sørensen and Cairns, 2015).

We are in the midst of a crisis in which sustainability, defined as 'the long-term maintenance of systems according to environmental, economic and social considerations' (Crane and Matten 2016, p. 33), is continuously threatened by corporate choices that privilege economic considerations and self-interest over care for communities, future generations and the natural environment. Managers exert considerable influence as a social group (Reynolds, 1998) and their training and education largely falls to business schools. Implicated in historically promoting a culture of excess (Ghoshal, 2005), business schools are increasingly called upon to develop more responsible managers (Hendry, 2006; Starkey and Tempest, 2009; Hühn, 2014) who, guided by moral values, consider their potential impact on all stakeholders (Nonet, Kassel and Meijs, 2016).

In response, many business schools have added modules on ethics or corporate social responsibility (Cornuel and Hommel, 2012) and devised new programmes devoted to these topics (Nonet et al., 2016). Moreover, a growing number of schools have signed up to the United Nations PRME (Principles of Responsible Management Education), signalling a commitment to integrate ethics, responsibility and sustainability into their curricula (PRME, 
Without effective guidance on alternative theoretical models and educational approaches, mainstream pedagogic strategies continue to reinforce a narrow, short-term and self-interested mentality (Catterall, Maclaren and Stevens, 2002) in which shareholder value is prioritised and success measured in purely financial terms (see Ghoshal, 2005; Hühn, 2014; Baden and Higgs, 2015). Consequently, people and the environment tend to be regarded primarily as inputs or resources to 'sustain the economy' (Kurucz, Colbert and Marcus, 2014, 439). Under such conditions, caring is often crowded out by the bottom line, as tragically illustrated by the disaster at the Grenfell Tower in London, which fireproof cladding (at an additional cost of $£ 2$ per square metre) could have prevented (Davies, Connolly and Sample, 2017). Essentially, students continue to be socialised into ways of thinking that undermine ethics (Giacalone and Promislo, 2013; Hühn, 2014) and threaten sustainability, perpetuating the very conditions that need transforming (Kilbourne and Carlson, 2008; Kilbourne, Dorsch and Thyroff, 2018). Ironically, this focus on the bottom line does not serve business either, as it fails to equip future managers with the skills they need to address the 'messy ambiguities' (the ethical, social and moral dilemmas) they inevitably face at work (Schoemaker, 2008: 121; see also Baden and Higgs, 2015).

A growing body of literature has championed critical approaches to management education that invite teachers and students to interrogate taken-for-granted assumptions, ideologies and managerial discourses, and to consider the contexts and dynamics of power underlying 
managerial thought and action (Reynolds, 1998; Gray, 2007; Cunliffe, 2009; Spicer et al., 2009; Śliwa et al, 2015). However, whilst critical approaches to management education provide a useful framework to expose harmful practices and problematize the conventional premise of the shareholder, they can do so by adopting too oppositional a stance. This negativity can produce knee-jerk defensiveness from students (Spicer et al., 2009), especially when they are indoctrinated into a culture that glorifies materialism and power (Giacalone and Promislo, 2013). Being expected to question their long-established beliefs and axioms can be disconcerting (Reynolds, 1999; Gray, 2007), particularly if students lack countervailing narratives. Importantly, even if students are receptive to such practices, this does not guarantee that they become more considerate of businesses' impacts; 'critical thinking does not in itself ensure either moral thinking or moral action' (Noddings, 2002: 39). Thus, we argue for a transformative agenda in education (see also Koehn, 2005; Dehler, 2009) - one that nurtures students' criticality alongside their moral imagination (Starkey and Tempest, 2009; Fougère, Solitander and Young, 2014), grounded in feelings of empathy, compassion, respect and care (Noddings, 2002; Gabriel, 2009; Spicer et al., 2009).

To contribute to this transformative effort, we applied the lens of care ethics (Gilligan, 1982; Noddings, 2002) in re-imagining and delivering a postgraduate module on Marketing Theory. Specifically, we assessed the potential for an ethics of care, which focuses on interdependence, responsibility and attention to the other (Held, 2006), to help students develop reflective and caring attitudes towards business by promoting emotional engagement and providing a learning environment in which they could feel comfortable applying critical thinking. In this paper, we share our experience of this intervention, and our students' response thereto.

We have organised this manuscript as follows: first we make the case that sincere care is 
lacking within management and marketing discourse; then, we introduce care ethics and examine its potential as a framework for critical management education; next, we discuss the method we used to examine students' experiences of our approach; we then discuss our findings and delineate a framework for adopting care ethics within management education, before drawing conclusions.

\section{Rhetoric of Care in Marketing}

Few managers can publicly question that their principal role is to create organisational wealth (Ghoshal, 2005). Because the 'bottom line' dominates decision making, defending an action with the 'language of care and compassion' (Gössling and Liedekerke, 2014: 438) is often challenging. This creates a 'caring-only-if-it-leads-to-profit' perspective (Machold, Ahmed and Farquhar, 2008: 671) that leads businesses to overlook environmental and social costs when profitable (Thompson, 1995). Indeed, many business students are already predisposed to privilege profit over caring when they begin their degrees, and those showing care for the vulnerable may be ridiculed as 'naïve', 'bleeding hearts' or 'softie[s]' (Giacalone and Promislo, 2013: 89).

Care raises specific questions for marketing. Marketing tends to be represented as a progressive force (see Hackley, 2003) that focuses on mutual satisfaction (Baker, 2016) and value for 'customers, clients, partners, and society at large' (AMA, 2013). However, market growth relies upon consumerism and materialism, ideals which are often at odds with care for people (e.g., consumers, workers) and the environment. Thus, mainstream curricula that remain narrowly focused on increasing profits, tend to be 'antagonistic to the key tenets of sustainability' (Baden and Higgs, 2015: 547). 
In contrast, our module was designed to expose the contradictions of the marketing discourse and support sustainability. Specifically, we challenged a view of consumers, workers and communities as abstract, distant groups and (re)introduce them into our discussions as 'real flesh-and-blood human beings, with feelings and families, with real cares and concerns' (Solomon, Zaichkowsky and Polegato, 1999: 3). This allowed us to consider new content and logic in which a 'cult of people (relationships)' replaces the 'cult of things' (Varey 2010: 118) and where fulfilment can also be found in non-material sources, including social ties and relationships (see Peattie and Peattie, 2009; Varey, 2013; Crane and Matten, 2016). In this article, we propose that care ethics can contribute to such a reorientation by offering students an alternative voice with which to challenge dominant assumptions and legitimate care in decision making.

\section{Care Ethics}

Care ethics is a moral theory that holds that care is 'central for understanding the nature of morality' (Timmons, 2002: 224; Gilligan, 1982; Held, 2006). This ethics reflects an approach to life and personal conflicts that is guided by 'feelings of responsibility for enhancing the wellbeing of others and a sensitivity to the interpersonal consequences of one's actions and choices' (Thompson, 1996: 401).

An ethics of care starts with an emphasis on our universal dependence on others from the moment we are born and the concomitant primacy of relationships in our lives (Held, 2006; Lawrence and Maitlis, 2012). Rather than seeing the individual as rational or autonomous (Tronto, 1995), this ethics develops around the core understanding that self and other are 
Caring demands attention to the context and idiosyncrasies of the cared for and of our relationship thereto; to care, or act as 'one-caring', is 'to act with special regard for the particular person in a concrete situation' (Noddings, 1984: 24). Looking at a particular other rather than the abstract, generalised other (Gilligan, 1982) encourages us to imagine the other's frame of reference and to act in order to protect or enhance their welfare (Noddings, 1984; Hawks, 2011). This is what Noddings (1984) calls engrossment and others refer to as empathy (Gilligan, 1982). This emotional sensitivity is important in that it guides moral action (Burton and Dunn, 2005; Held, 2006). When we view another person as concrete rather than abstract, our feelings of moral responsibility towards them are aroused (Thompson, 1995) and we can envision new ways of acting towards them. A photograph of the three-year-old Alan Kurdi, lying dead on a beach, gave a name and a face to the refugee crisis that demanded compassion and action. Likewise, the deportation and loss of rights of people from the so-called Windrush generation garnered heightened public and political attention once concrete stories of these individuals were shared. 
The origins of care ethics are found in the works of Gilligan (1982) and Noddings (1984), who see a care perspective as a legitimate and perhaps superior alternative to Utilitarianism and Kantianism (Sander-Staudt and Hamington, 2011). In contrast to these more prevalent ethical positions, an ethics of care does not focus on prescriptive rules (Koehn, 2011) or universal principles (Burton and Dunn, 2005) but, rather, on understanding the 'concrete context and particulars' of that situation and responding with consideration for the well-being of all involved in the relationship and those affected by the actions taken (Hawk, 2011: 14). As Gilligan (1982: 174) explains, while an ethics of justice starts from 'the premise of equality', an ethics of care 'rests on the premise of nonviolence - that no one should be hurt'.

Thus, an ethics of care is thought to offer superior ways of addressing contemporary business challenges (Burton and Dunn, 2005), including sustainability (Sander-Staudt and Hamington, 2011; Paillé et al., 2016). Its attention to context, relationships and moral sensitivity fits the complexity of contemporary business decisions and the environment in which managers operate (Burton and Dunn, 2005; see also Thompson, 1995) in ways that seem more realistic (Engster, 2011) than those provided by abstract principles. People entering an organizational setting bring their emotions and values with them (Nelson, 2011), and exist within a web of personal and organisational relationships (Hawk, 2011), which influence their decisions.

In this light, an ethics of care is uniquely well placed to advance stakeholder theory (see Burton and Dunn, 1996; Wicks, Gilbert and Freeman, 1994) as it encourages us to replace a view of corporations as autonomous and competing entities with a model of corporations as networks of relationships between people (e.g., employees, customers, communities) who give meaning to and define the corporations (see Burton and Dunn, 1996; Wicks et al., 1994). While it is relatively easy to prioritise self-interest (profit) over an abstract group of stakeholders, 
acknowledging them as concrete individuals heightens our sense of responsibility towards them (Palmer and Stoll, 2011). Thus, the empathetic approach supported by such ethics may help businesses to take to heart those whom they affect unintentionally (Koehn, 2011), including future generations (Wicks et al., 1994), disadvantaged consumers, communities and other species (see also Burton and Dunn, 1996).

A care-ethical focus on the interdependence and needs of those 'for whom we take responsibility' (Held, 2006: 10) highlights our responsibilities as educators towards our students (Noddings, 2002) and sensitises us to the impact of our teaching on their future actions. Drawing on this ethics, our classroom became a space in which to nurture sensitivity towards the wider impact of business practices.

\section{A Care-Ethical Framework for Responsible Management Education}

Marketing Theory was a compulsory module for students registered on a one-year Master's in Marketing at a PRME-affiliated Business School within a Russell Group, UK University. The module was critical in orientation and taught classical and contemporary theories, concepts and developments in marketing, including: consumption, critical marketing, sustainability and macromarketing, as well as ontological and epistemological debates in the discipline. Our approach was informed by care ethics and the practices we used were designed to facilitate critical engagement and moral sensitivity. In the following we discuss the main dimensions of this approach.

Providing a Critical and Caring Approach to Learning 
For critical thinking to guide responsible behaviour, it requires a foundation in moral sentiments. As Noddings (2002: 44) argues, we need to care 'about the people, causes and problems to whom and which we apply our thinking skills' (see also Thayer-Bacon, 2000). Without this, reasoning risks becoming mere sophistry, equally able to legitimise wrongdoing as to guide virtuous behaviour. Noddings (2002) illustrates this with reference to Harriet Beecher Stowe's novel Uncle Tom's Cabin. Within the novel, Mr Shelby is able to argue in favour of selling two slaves away from their families. Shelby's wife, thinking of the issue in terms of particular people whom she knows, cannot accept this. As Noddings (2002) notes, the Uncle Tom's Cabin story has created an emotional involvement with the lives of slaves that stressed the wrongness of slavery to great swathes of the American population.

Thus, while an ethics of care favours critical awareness of the idiosyncrasies and contexts in which judgments are made, it also encourages us to reach towards those affected by these decisions, with feelings that respond to their conditions (Noddings, 2002; Held, 2006; Thompson, 1995). In other words, this ethics has the potential to nurture more reflective modes of thinking, attendant to conflicting demands (Timmons, 2002), as well as to procure critical thinking with the moral sentiments required to guide responsible decisions.

Inspired by this ethics and joining transformative efforts of critical management education (e.g., Reynolds, 1998; Gray, 2007), we employed a variety of learning activities and pedagogical tools, to facilitate students' critical and emotional engagement. Thus, we exposed students to readings and perspectives that support (e.g. O'Shaughnessy and O'Shaughnessy, 2002) and challenge mainstream thinking in marketing (e.g. Alvesson, 1994), and helped them to engage critically and reflexively with those materials (Appendix, example 1). In one session, we offered insights into the social construction of marketing by reviewing changing definitions 
of the concept and considered whether the American Marketing Association's most recent definition (AMA, 2013) renders it more inclusive of marketing's effects on society, or if this is little more than 'window-dressing' (Tadajewski and Brownlie, 2008: 6).

In our efforts to counter simplistic axioms of mainstream pedagogy, we sought to foster a more nuanced understanding (Dehler, Welsh and Lewis, 2001) of marketing discourses and practices. For example, we asked students to reflect upon whether marketing responds to consumers' needs or creates them, based on their own experiences with marketing, and to consider how the dominant social paradigm of western societies may facilitate environmental decline (Kilbourne and Carlson, 2008). Informed by the emancipatory project of Critical Theory (Alvesson and Willmott, 1992; Alvesson, 1994; Reynolds, 1998), we sought to create conditions for students to re-imagine marketing (and market systems) and challenge the assumption that established ontologies are inevitable (Fournier and Grey, 2000; Tadajewski, 2018).

Throughout the module, students were encouraged to consider and empathise with different stakeholders paying particular attention to vulnerable consumers. We demonstrated such behaviours in our teaching in an attempt to model care and to support students' efforts to also become ‘one-caring' (Noddings, 1984: 178; see also Giacalone and Promislo, 2013). Thus, for example, rather than dismissing the effects of marketing on consumers with caveat emptor, we reflected on how marketing can affect particular others (e.g., a young girl bombarded with images from the fashion industry) and on the inter-related nature of us and those others (the girl is depicted in the Dove campaign video 'Onslaught' as 'your daughter'). In considering environmental sustainability, we drew upon readings that represent contradictory discourses regarding marketing's impact (e.g., Peattie and Peattie, 2009; Varey, 2010) and asked students 
to engage with these viewpoints in light of their own experiences. To provoke discussion, we considered if it was 'self-evidently pointless - stupid even - to consume more to generate wealth in an attempt to fix the problems caused by consuming more!' (Varey, 2010: 114). We invited students to critically reflect upon an advertisement claiming that fur was 'eco-friendly' and another from Peta.org.uk ('Try telling him it's just a bit of fur trim', the image of which depicted a fluffy, white rabbit) to nurture emotional engagement with animal cruelty and with marketing's and consumers' responsibilities therein. Another activity required that students considered marketing's benefits and effects from particular points of view (e.g., a consumer, a representative from a consumer advocacy group, a marketing manager), so that they could empathise with different stakeholders (Appendix, example 2). Collectively our efforts allowed students to appreciate that moral dilemmas involve judgments about different stakeholders and the priority to give to each (Thompson, 1995).

Following Noddings (2002), we further drew upon arts and drama to enhance students' critical reflection and emotional engagement (see also Beirne and Knight, 2007). For example, Magritte's painting 'Ceci n'est pas une pipe', provided a good starting point to involve students in critical thinking. Likewise, we wrote and enacted a short play to initiate debate about several philosophical issues pertaining to the discipline and illustrate disagreement in an open, humorous tone. By making ourselves vulnerable (acting rather than teaching) we disrupted the traditional power dynamics in the classroom.

\section{Acknowledging the Student as a 'Concrete Other'}

As an approach to teaching, care ethics emphasises the relationship between the carer (educator) and the cared-for (student) (Noddings, 2012). Rather than treating students as 
interchangeable and subject to general principles (as in conventional 'ethics of justice'), we considered each student as special (Gabriel, 2009), and aimed to 'preserve or promote an actual human relation' (Held, 2006: 12) with each one. This required knowing their names and backgrounds, and making efforts to appreciate each student.

We encouraged students to reflect upon and share their individual experiences of the topics discussed. In one lecture, students were asked to bring either a special possession, or a oneweek record of their purchases (and the motivations therefor), and to discuss these in light of the readings for that session. We used the diversity in the classroom to find examples from students' cultural experiences. This was intended to enhance students' confidence and selfesteem, engage them emotionally and intellectually with the matters at hand, and promote an environment in which they expected not only to listen but to be heard. In keeping with a reflexivity agenda (Gray, 2007), this allowed us to remove critique from purely intellectual or abstract dimensions and encouraged students to question their own views and practices (see also Cunliffe, 2002). Outside these interactions we, teachers, shared notes and observations about the students, trying to understand each of them, their struggles and engagement in the module.

\section{Providing a Safe Environment to Learn}

A care-ethical approach to teaching necessitates a 'climate of care and trust' in which critical thinking and moral reflection can flourish (Noddings, 2012: 777). We appreciated that engaging in critical thinking can be especially challenging for students unused to an educational, or cultural, system that privileges questioning. As in other universities that have successfully globalised (Starkey and Tiratsoo, 2007), many students came from knowledge- 
centred (Wallace and Wray, 2011) cultural backgrounds (e.g., China, India) where loyalty and tradition are honoured (Gabriel, 2009; Śliwa et al., 2015) and rote learning is privileged (Bradshaw and Tadajewski, 2011). As a result, students often feel anxious about (Brookfield, 1987) or 'intimidated by the sudden emphasis on what they think' (Wallace and Wray, 2011: 8). We understood that even when students embrace criticism of a system, they can feel disempowered, believing they lack the capacity or agency to effect change (Giroux, 1981). Informal conversations with students at the start of the academic year corroborated these impressions.

Informed by care ethics, we set the ground rules that students should respect one another, that we would respect students, and that their insights were welcome. We tried to be empathetic towards students' observable difficulties and to create a friendly environment in which we would listen to their needs (Noddings, 2012) and they could feel safe to speak their mind. Whilst team-teaching, we were comfortable in disagreeing with each other in a way that modelled constructive and engaged debate.

\section{Valuing Emotional Engagement}

Students' exposure to a broad understanding of businesses' effects on others can arouse strong feelings. We created an environment in which showing emotions (e.g., compassion, excitement, anger) was valued and encouraged students to use their emotions in moral decision making (Thompson, 1995; Held, 2006; Giacalone and Promislo, 2013). Even anger can reflect moral indignation and thus contribute to an appropriate interpretation of wrong actions (Held, 2006; Simola, 2011). Looking, for example, at specific situations where people or natural habitats were affected by marketing helped to arouse such sensitivity. 
To further naturalise care and create a space for emotion in the classroom, we also expressed our feelings about the topics at hand (e.g., showing distress about animal testing for cosmetics). This contrasted with predominantly rational approaches towards business that may so often 'disparag[e] virtue' (see Giacalone and Promislo, 2013: 90). Ultimately, we hoped, it opened up the possibility that emotion can (and should) inform business decisions.

Cumulatively, our pedagogical approaches were designed to promote a positive atmosphere in the classroom, support those who were anxious about challenging authority, engage students emotionally and provide opportunities to think critically.

\section{Methodology}

Having re-designed the Marketing Theory module to be both critical and caring, we reflected on students' experiences on the module. Our observations in the teaching sessions suggested that although students started off timid or resisted participating, they gradually became more at ease and eager to voice their views. Students' performed well on assessment, with a higher average mark than the previous three years ${ }^{1}$.

Formal evaluations of the module and the teachers were also very positive, with some students specifically raising that it was caringly delivered. While these results were encouraging, we were interested to find out more. We decided to investigate students' experiences of the module

\footnotetext{
1 Students were evaluated by an individual assignment $(50 \%)$ and by an exam (50\%). The contents and requirements for both were similar to those in previous years. In both cases their performance was better than in previous years. The final average of their marks was 63.7 while in previous years it was 59 (2012/13), 58.6 (2011/12) and 59.6 (2010/11), with the same team of lecturers for the all years except 2010/11, when only one of the authors taught this module.
} 
further.

We used a semi-structured interview guide to interview our students in depth. This ensured balance between consistency and focus on the one hand and flexibility on the other. Thus, we could give proper attention to issues that we wanted to explore while participants had space to discuss their views and experiences freely and raise any additional topics of relevance (Kvale, 1996). Data were collected several months after students completed the module and after their marks were given; the university's ethics panel approved this data collection. Our questions were open and focused on students' experiences of the masters as a whole (e.g., what they enjoyed or found challenging, memorable learning). Many participants shared their experiences of the Marketing Theory module spontaneously, without prompting. This indirect means of collecting data regarding our module avoided students feeling pressured to give undue weight to particular topics or agree with specific viewpoints. All students (twenty-seven) were invited to participate in this study; we interviewed all (thirteen) who replied to the invitation within the time frame for the data collection. To preserve anonymity, we use pseudonyms (including when students referred to their colleagues by name) and group their countries of origin into regions (see Table 1 in the Appendix for a list of the participants). Three years after graduation, we revisited those participants for whom we could find current contact details. We were able to contact four participates in order to obtain retrospective accounts of their experiences. This was to assess whether our approach had any lasting impact on these students' attitudes.

Interviews were recorded, professionally transcribed and subjected to interpretative analysis (Kvale, 1996). We read the data carefully and repeatedly, reflecting upon the themes and concepts we were trying to explore and uncovered emerging patterns (Rubin and Rubin, 1995). 
Our theoretical assumptions informed our interpretation (Taylor and Bogdan, 1998), which drew heavily on the care-ethics literature. We also kept records of observations from the classes, which helped in understanding students and maintaining a caring approach.

\section{Students' Experiences of a Care-Ethical Approach to Learning}

The outcome of our care-ethical approach was the creation of a supportive environment in which students could develop the confidence they needed to critically analyse ideas. This helped them both develop moral sensitivity and practice being 'one-caring'. Next, we present our findings organised around four key themes, which illuminate students' responses to our approach.

\section{Appreciate being valued (I matter)}

Students' accounts show they appreciate being recognised as unique people 'with different backgrounds and different issues and different kind of ideas' (Maleeha), not just 'a collective group of a number of students' (Maleeha), or 'a number' (Ajla). In particular, faculty using students' names made them feel 'really special', as highlighted by Ajla and Petra. Acknowledging each student as 'a concrete other' (Held, 2006) encouraged the belief that 'the teacher cares about you as an individual in the class' (Catherine). This can have an important impact on students' self-esteem and experiences:

'if you feel that people care about you and they respond to your needs as fast as they can and make you feel, not important but well yes, let's say important. [...] You actually feel sort of at home here ... So, I thought that is very important, yes definitely. I mean 
that makes the experience worthwhile.' (Moritz)

Students considered it 'helpful' to connect the material to their experiences. This was particularly valuable for international students, enabling them to better relate to the lecture materials and to feel 'less lost':

'if they [lecturers] can use international examples, like always they're using UK, UK examples, so we feel lost. It's only a few students who can carry along with these examples $[\ldots]$ we did in Marketing Theory like when we did the green marketing, so every student said examples from their country... So it was easy for us and helpful.' (Dana)

Some students, like Wang, found the opportunity to reflect on a personal possession particularly helpful:

'[I]n one class you asked us to bring our own items for this class $[\ldots]$ we felt more confident, comfortable to say something maybe not very academic but very close to our life that can be seen from an academic perspective [...] I loved this class, I learned more about it.' (Wang)

Essentially, reflecting upon their own experiences helped to make 'knowledge personal' (Catterall et al., 2002: 189) and counteracted the abstract way in which marketing scholarship is often approached. This further served to foster emotional engagement with the material rather than passive acceptance. Nuwanthi said that this made her 'feel happy and proud ... about myself, about my culture'. 


\title{
Feeling safe to think and share (I can speak my mind)
}

As anticipated, this module can be particularly difficult for students whose educational or cultural background privileges memorisation over questioning. Students' accounts of their initial experiences with the module highlight the anxieties and dynamics of power that can impact their learning (Brookfield, 1995):

\begin{abstract}
'I remember the first time we were talking about critical thinking and ... it was scary at first ... Like "these are what we expect from you", especially the first lecture, like this and this and this; "I am expecting the essay and you need to think critically..."” (Amina)
\end{abstract}

'I didn't know that we have to like take that certain journal, you need to see the author's point of view. Usually I would read, I would understand and that was it. Yeah, I would not try to criticise him because he is more knowledgeable than me at the end, yeah. But this [module] helped a lot. [...] it didn't provide me just with the information; it gave me like a guide for the other modules.' (Adi)

This problem is exacerbated when students have difficulties communicating in English, which may leave them fearing 'saying the wrong thing' (Petra), being 'laugh[ed]' at (Ning) or being seen as 'stupid' (Marie). As Adi expressed:

\footnotetext{
'The language ... it's a very big barrier [...] But [the lecturers] calling by name maybe, asking "what do you think?", saying it doesn't have to be right ... and you were actually doing that ... it helped'. (Adi)
} 
Informed by Noddings $(1984,176)$, we understood that asking a question means receiving 'not just the 'response' but the student'. Thus, how the lecturer takes in a student (and their effort and struggles) affects that student's emotional responses and their disposition to participate in the future. Most of the students interviewed referred to this spontaneously.

\begin{abstract}
'because if you give an answer and the teacher ... either looks at you blankly completely or just doesn't really give a great response, then you kind of feel 'okay, maybe I don't want to answer again.' [...] But if they kind of encouraged you, I mean I feel like there's ways of kind of telling someone that their answer may not be right, I think you could say that you know, that's a good point or good suggestion [...] the students will want to actually participate without having the fear that your idea's going to be kind of put down.’ (Maleeha)
\end{abstract}

This and other students' accounts illustrate the importance of attending to their emotional needs. Our commitment (both in and out of the classroom) seems to have been noted by some, as were our efforts to model the behaviour that we sought to encourage:

\footnotetext{
'When a teacher looks at me and says 'You can do it'... when you told me 'You will be fine' ... 'You will do well', like it makes me feel like it's okay, it's fine, it's going to be okay, I feel motivated to work.' (Priya)
}
Our use of humour seems to have further facilitated a friendly learning atmosphere, which helped students overcome their fears:

'... and another thing is being humorous, it's very, very important... it relaxes us more. 
And because I feel very lucky to have been in this class... if I can say it was very humorous in the class [...] all very friendly. So no need to be afraid' (Wang)

'The play... I can't forget that! I can't forget that! It helped a lot. I liked that a lot; it was very, very interesting. I have never [had] that before in a class.' (Adi)

For relations to be caring, the cared-for must recognise the efforts of the carer as caring (Noddings, 2010). It was reassuring to observe students' engagement and welcoming expressions in the classroom suggesting that we were on the right track. This also seemed to move students beyond consideration of their own self-interest and to explore opportunities to 'give back', as illustrated in Moritz's account:

\footnotetext{
'you want to give something back if you're taken care of. So, you want to come prepared and yeah, try at least to give your best and be honest if you're like ah, this is busy times and I'm not really prepared but ... you know, yeah, be honest to each other and really try to have this respectful relationship [...] you feel taken care of, people help you, I mean what you're offered during the Marketing Theory [...] And then yes, sure, if you have the opportunity you want to give back because that's just like the giving and taking, it should be a mutual thing.' (Moritz)
}

\begin{abstract}
Thus, it seems that modelling respect and care towards students enhanced their motivation and engagement and their appreciation of the interrelatedness of the faculty and students (a 'respectful relationship', in Moritz's words). This fuelled our own motivation to further invest in our efforts, creating a virtuous circle.
\end{abstract}




\title{
Enhanced emotional and moral engagement, and critical reflection: others matter
}

As a result of participating in this module, students expressed emotional involvement with marketing and its impact on society. This, however, was not always a comforting experience given that career choices had already been made:

\author{
'Sometimes I wish I didn't learn this part because it makes me feel bad that I am \\ participating like in this'. (Amina)
}

Other students spoke of business practices in much more emotional terms than was previously the case:

\begin{abstract}
'I realised the impact that marketers can create in the society. I felt angry and sad about the big corporates who practice hypocrisy. Even though they try to create a good image about themselves using the Dove campaign, saying 'the beauty is within you', on the other hand they put an enormous pressure towards coloured people highlighting the beauty standard of being white. [...] I felt it is racist. [...]. They use these beauty standards to promote their 'Fair and Lovely' fairness creams in most of the browndominant countries and almost all the vulnerable girls who are brown or darker in complexion feel insecure about the way they look.' (Nuwanthi)
\end{abstract}

Here we see emotions featuring heavily in Nuwanthi's response, in which she articulates how she experienced the 'Fair and Lovely' campaign as racist and damaging to dark-skinned girls. Nuwanthi's anger signals the 'ethically concerning dimensions' of the situation (Simola, 2011: 131). Her feelings are intertwined with a growing critical awareness of marketing's 
contradictory discourses and the potential impact of this campaign on herself and others. In a similar vein, Priya expresses a nuanced concern about marketing's impact and her moral obligation to consider such impact as a future marketing professional:

\begin{abstract}
'It's important to discuss those [affected by marketing] because we need to know the ethical issues around vulnerable consumers, around environmental issues ... I think it's important that you can't just assume that we understand that concept you know, I think I'm glad that you taught it to us in a way that makes you think about the issues [...] maybe you have a marketing idea tomorrow... I will go back and reflect on what I have learnt in class, simply for the fact that I would think, is it ethical? Am I doing the right thing? [...] It's like the elephant in the room ... Like you can keep talking about the benefits of marketing and the profit side of marketing and how it's influencing consumers... but you have to address the downside of all that. Because everyone's concerned what's going to happen with the next generation. And if we don't think about it ... we're going to be professionals in this field ... so if we don't think about it who else is going to think about it?' (Priya)
\end{abstract}

Priya demonstrates critical thinking grounded in a moral framework, which eschews a distant, 'dehumanizing' (Stoeckl and Luedicke, 2014: 21) view of businesses' actions, based solely on profitability. Her use of the expression 'the elephant in the room' shows that she now perceives the rhetoric of marketing as being dangerously blind to what should be obvious dangers. As students' sensitivity towards the effects of businesses on others grows, there is strong evidence of empathy, 'a feeling of moral responsibility for the plight of others' (Thompson, 1995: 182), as illustrated by Catherine: 
'[With Marketing Theory] we did get that part [profit] but in a more educated way, in a more humane way and... because we didn't see ourselves just as the provider of a good but sometimes, when I was doing the class, I was putting myself in the consumer's point of view, or... I was a person buying the product ... would I be comfortable with the way it's sold to me? That actually affects a lot...' (Catherine)

\begin{abstract}
Moritz, below, also internalised a new way of looking at marketing; this shift in perception of what marketing is (or can be) enabled him to imagine new, more responsible ends for marketing practice. Moritz's concern with the impact of marketing and his question 'how can we actually use marketing as a tool to make the world a better place and not only to generate more money?' demonstrates an enhanced moral awareness that is consistent with a caring approach, and contrasts with his previous acritical view:
\end{abstract}

'I think that was actually the most essential thing of this course that had changed at least my perspective if I talked to ... I think it was Emily and Petra as well... That the course changed our perception about marketing because when I had it at undergrad it was just this is the full piece, this is going to work [...] But there was never the argument about... the impacts of marketing because it's basically encouraging people to consume. What are the impacts, as you say of green marketing and the sustainable marketing approach; how can we actually use marketing as a tool to make the world a better place and not generate more money? So that was actually something that did change my perspective about marketing and also the whole business environment. [...] And that was actually very, very nice because a couple of us realising during undergrad it was just you know, opening 
your brain and throwing all the marketing content in there without actually reflecting on it.' (Moritz)

Moritz's narrative is also illustrative of his realization of how his own perceptions of marketing and business had been shaped and constrained by his learning experiences. Similarly, other stories showed how students' new perspectives offered them 'more realistic' understandings. Priya's account, below, further stresses her enhanced moral reasoning; one that is based upon what one should do, rather than merely what one can do:

\footnotetext{
'We used to come back from the class and discuss [...] So things like that, like it makes you think about the life from a realistic perspective, you can't just go about thinking... Just the profit side and making money; there has to be a point where you draw a line, you think about can I do this? Should I do this? ... So ... it's good to be exposed to that, to force you to think about it. Sometimes you might ... you know about it but you are in denial of these issues, so to force you to think about it I think is definitely necessary'. (Priya)
}

That Priya, Moritz and others felt compelled to prolong discussions outside the classroom demonstrates that they were practicing their capacity for reflection, something that Harris (2008) regards as fundamental to the development of ethical wisdom. These students were able to problematize their previously uncontested understandings (Gray, 2007) and engender reflexive conversations or dialogues of these matters in light of their own experiences (Cunliffe, 2004).

These students' views lay in sharp contrast to the prevailing materialistic worldview, focused 
on discourses of power, self-interest and profit (Giacalone and Promislo, 2013). This is especially relevant given some students' initial reluctance to engage with material not aimed directly at improving their effectiveness as managers, as suggested by ironic facial expressions or a tendency to be dismissive (e.g., 'But what about making money?'). They seem to have learnt to appreciate the effects of the discipline on others and that to care about them is not a question of being 'soft' (Giacalone and Promislo, 2013) but, rather, a requirement of morality.

\section{Empowerment (I can and should make a difference)}

Students' enhanced moral awareness empowered many to believe that they could, and should, 'create a better world'. This notion that caring can be empowering was also found in Pratesi's (2011) sociological study of caregivers and further resounds with the liberating potential of Critical Management Studies (Spicer et al., 2009). Thus, we can begin to appreciate how this approach can facilitate not only an enhanced moral awareness but also behavioural change. This idea of growing into a 'better person' who can do 'great things' is poignantly outlined in Nuwanthi's narrative below:

\footnotetext{
'After the module I realised the whole course was focusing on creating a better human being rather than a mere professional, which is the most needed thing in the contemporary world. These humans will be able to do greater things to create a greater world [...]. I think the aim of education is like not to train him to go to the job market, like train him to earn money or something. He should do something ... he or she should do something impactful to the society at large. So teachers should keep that in mind. It's not just about the knowledge, it's about the humanity and it's about how you are going to ... what is the impact that you are going to make to the world at large?' (Nuwanthi)
} 
Nuwanthi's distinction between becoming 'a mere professional' and 'a better human being' is interesting; significantly, her conception of 'better' includes moral obligation to effectively change things. Indeed, some students chose dissertation topics inspired by the module. For example, Wang decided to apply his newly acquired insight on sustainability 'to help with the problems of serious environmental pollution caused by companies in [his] country' while Nuwanthi pursued doctoral research in social marketing. Now in her third year she retrospectively explains her decision as follows:

\begin{abstract}
'It certainly motivated me to select the topic of my $\mathrm{PhD}$. I always knew that marketing should be looked at from a different perspective to stop the destruction that it has created. But I did not have a clear idea on the approach. I was never exposed to any subject that was not in mainstream marketing. When I started learning Marketing Theory it made me to think that I can be useful not just for a company but for the society at large.' (Nuwanthi)
\end{abstract}

\begin{abstract}
Thus, these and other students' narratives show a desire or commitment to use their broadened awareness to influence the practice of marketing. From a care-ethical perspective, this sense of empowerment is valuable. Rather than fostering dependence (Noddings, 1984), caring is about nurturing the growth and future well-being of the cared-for (Gilligan, 1982; Ruddick, 1980), respecting their autonomy and enhancing their ability to make their own choices (Liedtka, 1996). In a retrospective account, Catherine, who now works at an advertising company, outlines how this influenced her:
\end{abstract}

'I think I might do it now in a less manipulative way since of... before I would just think: oh, how can I address that person so that I can benefit from buying my product, now it's 
more of, considering the other person as well [...] the process of critical thinking actually helped me not just during the master's... now I'm just applying... in everything I do... I mean it kind of becomes a second nature actually, don't just do what we want because it will benefit us but think of the other person.' (Catherine)

Catherine highlights that not accepting things at face value (critical thinking) and considering the impact of her actions on other people (caring) have become second nature to her. This does not always make her working life easier; indeed, her first job did not work out because it created moral dilemmas that she could not resolve. Even in her current position, the realities of organisational life mean that effecting change is not always possible. Despite this, she often chooses to voice her concerns, which is the only action that she can effectively engage with at this stage of her career:

\footnotetext{
'So sometimes your sales objective might go against a moral awareness. You would do because I'm working as a consultant, so basically I'm a middleman between the actual company that produces the service and the customer so, sometimes, it's my job to go to the person selling the product "are you sure you want to address it like that because that might have some consequences?", but ultimately you're not the person taking the decision, you have to comply with what the company wants because you want to keep your job (laughs). But it does, it does have an influence on the way that I would feed back to my client on the product... on the advertisement I would produce for them.' (Catherine)
}

Priya describes similar challenges to her professional and life choices, created by an enhanced critical and moral awareness, which she sees as entwined: 
'I think when you're able to analyse things different, critically you can see... if it's ethically incorrect... it's all inter-related... you start questioning more, you end up thinking that it is wrong...' (Priya)

\begin{abstract}
Another student, Amina, says that participation in the module altered her behaviour both as a practitioner and as a consumer, rendering her more mindful of companies' claims and effects. Thus, although it is not possible to determine if our pedagogical approach helped to develop our students into people 'capable of thinking critically, reflecting critically, and engaging in critical action' (Barnett, 1997: 1), our perception is that they grew sufficiently in confidence to engage in critical thinking and, importantly, voice their moral concerns.
\end{abstract}

\title{
Discussion
}

This module was designed to encourage a critical and caring approach to learning in order to facilitate a more responsible mentality towards business practice. When intertwined, we believe that these two modes of thinking enable students to engage more deeply with the consequences of marketing decisions than they would normally. As a result of our experience, we propose a framework for applying a care-ethical approach to teaching and learning, which is illustrated in Figure 1. Our approach is not meant to be a definitive list of guidelines to be followed in order to develop 'caring' students. Rather, it represents an attempt to lay the groundwork for informed dialogue about the place of caring in management education and the conditions required for it to flourish.

\section{Insert Figure 1 A Care-Ethical Framework for Teaching and Learning Here}


The first column represents our actions towards enacting an ethics of care in the classroom, which included encouraging critical reflection upon how the 'things we know' about marketing knowledge and practice come to be accepted, and awareness of the inter-relatedness of those impacted by marketing systems. This also involved considering each student as a unique person, with strengths, challenges, interests, experiences and emotions, and concerning ourselves with their well-being. This facilitated a safe environment for students to participate and express views contrary to others. We consciously set out to model the behaviours we were encouraging (O’Malley, Fowler and Moore, 2016) - we were not just 'talking care', we were also being 'one-caring' (Noddings, 1984: 30), in the ways we approached others and the matters at hand. Thus, critical thinking was not merely a dry analysis of arguments but was interwoven with opportunities for empathetic engagement (Noddings, 2002) with the people, ecosystems and problems being considered. This was particularly important to encourage students to consider managers' moral responsibility towards the particular others impacted by their decisions and, more generally, to cultivate care and respect for others' rights and circumstances (see Held, 2006).

These conditions helped students to develop themselves as reflexive 'ones caring'; students could appreciate that they (and their opinions and experiences) mattered and that others did too. Growing in confidence and sensitivity empowered them to challenge assumptions and practices (including their own) and to effect change; students (at least some of them) felt compelled to 'give back' to society and apply their enhanced skills when making real-life decisions. Although not all students showed signs of similar lasting commitment, in the more immediate term, most students 'gave back' in the classroom through their engagement and effort. This is fundamental in an ethics of care which emphasises the importance of 
relationships; when the cared-for (students) give back to others (e.g. environment, teachers, colleagues), they are themselves acting as one-caring, which has the potential to initiate multiple relations of caring and disseminate the caring mentality. On the contrary, and as Catherine told us: 'If you don't show people care, why would you expect them to show care for others?'.

Most of our students were responsive to the experience of being 'cared for'. Their engagement with the module, performance and accounts of their experiences suggest that our approach facilitated a reflective mentality towards businesses and marketing and the effects thereof, in which the future adoption of responsible business practices can be solidly founded. Indeed, as some of these accounts indicate, this could have had a formative influence in the ways students behaved in their future experiences. This notwithstanding, we do not presume that our module has 'magically transform[ed]' our students into 'critical' (Dehler, 2009: 41) or caring individuals. Rather, the extent to which they engaged with the module and with the ideas discussed therein, was greatly informed by their previous experiences, skills and socio-cultural backgrounds (Śliwa et al, 2015). Perhaps by tapping into students' individual experiences and encouraging their reflection, we provoked in them a deeper and longer-lasting effect than we would otherwise.

Appreciating our students' journey, we were also compelled to reflect on our own experiences (Gray, 2007). We acknowledge that our approach was influenced by our own assumptions, backgrounds and research interests (see also Śliwa et al., 2015). Although we were keen to avoid the kind(s) of 'superior moralizing' (Reynolds, 1998: 194; Alvesson and Willmott, 1992; Samra-Frederiks, 2003) that are sometimes associated with critical pedagogy, we may not have always succeeded. We also appreciate that the emancipatory thinking (Reynolds, 1998) arising 
from making students aware of the assumptions and power relationships underlying the discipline is not without cost (Alvesson and Willmott, 1992) for them, either now (as students/consumers) or in the future (as employees and managers). Significantly, there is a 'price of integrity' (Giacalone and Promislo, 2013: 95), as illustrated by Catherine's termination of her previous job. In this regard, we may have underplayed care for them. Mindful of this, we attempted not to vilify managerial discourses or dismiss the merits of those in power, as well as appreciate the complex context in which they operate. In this sense, we hope to have demonstrated the value of managing all people (students, customers, employees, shareholders) in a responsible fashion. This, we expect, is the outcome of an equal commitment to care and criticality in our approach.

\section{Conclusions}

We are reminded, daily, of a range of humanitarian and ecological problems that urge us to consider the inter-relatedness of human beings and the planet. As nations around the world vote for tighter borders, we seem to be moving further from George Eliot's call for 'a more active admiration of those vital elements which bind men together and give a higher worthiness to their existence' (Eliot, 1955: 472). Amidst intensified calls for increased engagement from educators and students (Bell and Bridgman, 2017) and attacks on business schools for their greed and short-termism (Parker, 2018), our approach invites educators to re-engage with their responsibilities towards students and society, and to create transformative classroom experiences. In this paper, we have discussed how care ethics can contribute to such an agenda, by helping to re-imagine management learning in ways that harness students' moral and critical engagement. Intended to advance applied insights into responsible management education scholarship, we offer an account in praxis of what such a learning approach might involve. We 
explored its impact on one group of students and proposed a framework to inform future work. In so doing, we join a growing conversation on the potential of these ethics to contribute to a more humane and sustainable agenda (Heath et al., 2016), especially in education (e.g., Noddings, 2002; Burton and Dunn, 2005).

At the heart of our approach is a conscious effort to intertwine care with criticality, such that students' capacity for critique is grounded in a compassionate and moral understanding that their actions impact upon others. We believe that consciously fostering a safe space for critique provided students with the confidence to engage with the matters arising even when some of them experience considerable emotional or cultural barriers to doing so. Moreover, replacing an abstract and distant view of 'others' with a more particular and empathetic understanding of people, animals and ecosystems, encouraged students to interrogate the assumptions and effects of marketing more actively and sensitively. We found that students who could engage in a dialectic between care and critique were able to produce thoughtful discussions of moral issues. Significantly, this not only allowed students to imagine new possibilities for individual and business practices but also compelled (at least some of) them to act accordingly.

Thus, we observed students questioning structures and discourses of domination in marketing practice and discussing ways in which it could be different, in line with the emancipatory ambitions of Critical scholarship (e.g. Fay, 1987; Alvesson and Willmott, 1996; Reynolds, 1998; Dehler, 2009). Some students noticeably took 'personal responsibility' for helping to effect such change (Gray, 2007: 497) in their future jobs, studies, country or consumer choices in general. In this sense, this work further contributes to Critical Management Education scholarship, by offering an empirically grounded explication concerning the potential of an ethics of care to propel students' reflexivity, autonomy and liberation. 
The value of this approach resided, therefore, in offering students an alternative discourse, a 'different voice' (Gilligan, 1982), within which care, as much as money, is legitimate. A conscious emphasis on caring and interrelatedness helped to denaturalise the abstract, and selfcentred rhetoric that is often treated as neutral in the business school and to destigmatise more empathetic reflection on moral issues (see also Giacalone and Promislo, 2013). This, we believe, enabled us to lift the course above the 'introduction to consumerism and careerism' that higher education may become without care (Gabriel, 2009: 383).

Our approach seems to have worked in a small postgraduate class but would clearly be very challenging with a larger group. Even in our case, this demanded a significant emotional investment and pedagogical engagement, which led us at times to compromise self-care, a fundamental prerequisite for care of others (Gilligan, 1982). Given the sharp rise in student numbers and the commoditisation of higher education (Parker and Jary, 1995; Bell and Bridgman, 2017), faculty may perceive themselves as lacking the agency and capacity to care for their students, and this will influence students' own capacity and willingness to care back. Addressing such substantive concerns requires engagement from teachers and policy makers and should be informed both by critique of the current system and care for those for whom we are responsible. Rather than dismiss the potential of 'softer' voices, scholars should more explicitly challenge the agendas and structures that undermine our propensity to care.

The framework discussed here, developed for a module on Marketing Theory, could be applied or adapted by teachers of other management modules. It would be useful to explore how our approach (or variants thereof) could be enacted in other fields and with different, and larger cohorts. Equally, future studies should further enquire into the potential limitations and consequences of, shaping the future lives of the different groups of students that we are caring 
for. In particular, with a significant, growing number of Chinese students coming to study in the UK, we should appreciate the cultural and otherwise political constrains on defiance that exist under authoritarian regimes and which may render transformative narratives difficult to grasp (see also Śliwa et al, 2015) and apply.

While care ethics offers a useful and compelling framework, its adoption in the classroom is challenging and demanding, both for teachers and students; it asks us to question the status $q u o$, to consider others and their perspectives, and to imagine the consequences of our actions and assumptions on concrete others. It exposes contradictions in assumptions, ways of viewing the world and our own thinking and practices. This may well cause distress, yet, it also encourages empathy and awareness of the inter-relatedness of humans and nature, and of our responsibilities towards others. Ultimately, this should inspire a renewed appreciation of the human condition and compel us (students and teachers) to envision new possibilities for action. We hope that at a point in history where caring sometimes seems out of fashion, our students will concern themselves, in their careers and lives, with the potential impact of their decisions upon a wide range of others and that they will deploy their critical skills towards moral ends. 


\section{Appendix}

\section{Example 1 - Learning Activity: Engaging in Critical Analysis}

This activity (developed in a tutorial session) aimed to develop students' critical skills whilst reading and analysing a text. We asked students to apply their skills to critically evaluate the O’Shaughnessy and O’Shaughnessy's (2002) and Kotler's (2011) papers. Students were asked to interrogate the texts using questions such as:

Who is the author?

What are the writer's assumptions and aims/interests in this text?

What kind of language (e.g., adjectives) is used?

In which context was this written? How could it have influenced the author?

What evidence is used to support the claims made?

What information is missing from the text?

We then asked students to compare these authors' views, argument and evidence with those of Alvesson (1994) (a reading we had discussed during a previous lecture). We concluded by looking at these against the criticism of O'Shaughnessy and O'Shaughnessy work by Abela (2006).

\section{Example 2 - Learning Activity: Representing marketing}

This learning activity required students to take one of four perspectives when identifying the benefits and problems of marketing. Students were also encouraged to advance specific examples that would corroborate their arguments. This exercise promoted the practical 
employment of critical thinking and the importance of empathising with different points of view. It also helped students to appreciate how different groups will represent differently the same phenomenon.

Drawing on a critical perspective, discuss what are the main benefits and problems of marketing taking the perspective of:

- consumers,

- consumer advocacy groups,

- marketing managers, and

- students of an MSc in Marketing.

You are asked to defend the position of one of these groups and construct a case for or against marketing. Write a summary of you arguments on the white boards to support your discussion. 
Table 1: List of Participants

\begin{tabular}{|l|l|l|}
\hline Name & Gender & Nationality \\
\hline Catherine & Female & Europe \\
\hline Nuwanthi & Female & South Asia \\
\hline Adi & Female & MENA ${ }^{2}$ \\
\hline Marie & Female & Europe \\
\hline Ajla & Female & Europe \\
\hline Petra & Female & Europe \\
\hline Amina & Female & MENA \\
\hline Ning & Female & East Asia \\
\hline Maleeha & Female & South Asia \\
\hline Moritz & Male & Europe \\
\hline Wang & Male & East Asia \\
\hline Priya & Female & Europe \\
\hline Mike & & \\
\hline
\end{tabular}

${ }^{2}$ Middle East and North Africa 
Figure 1: A care-ethical framework to teaching and learning

\section{Student as 'cared for'}

\section{Providing a critical \& caring approach to learning}

- Encouraging students to engage with different viewpoints and to consider the impact of management (and their own) decisions, on specific others;

- Nurturing empathy;

- Fostering and Modelling 'caring' behaviours towards others, especially those in disadvantaged positions

\section{Acknowledging the Student as a Concrete Other}

- Avoiding impersonal approaches to interaction by using students' names, and trying to learn about them;

- Inviting students to bring personal artefacts, experiences and stories to the classroom that are meaningful for them and to have their voices heard.

Providing a safe environment to learn

- Acknowledging challenges to learning (e.g., limited exposure to critical thinking, cultural barriers) and emotional investment of students

- Designing supportive pedagogic practices in response

\section{Valuing Emotional Engagement}

- Encouraging students to bring their emotions into the classroom and to appreciate their moral value

- Destigmatize the 'language of care'

\section{Student as 'one caring'}

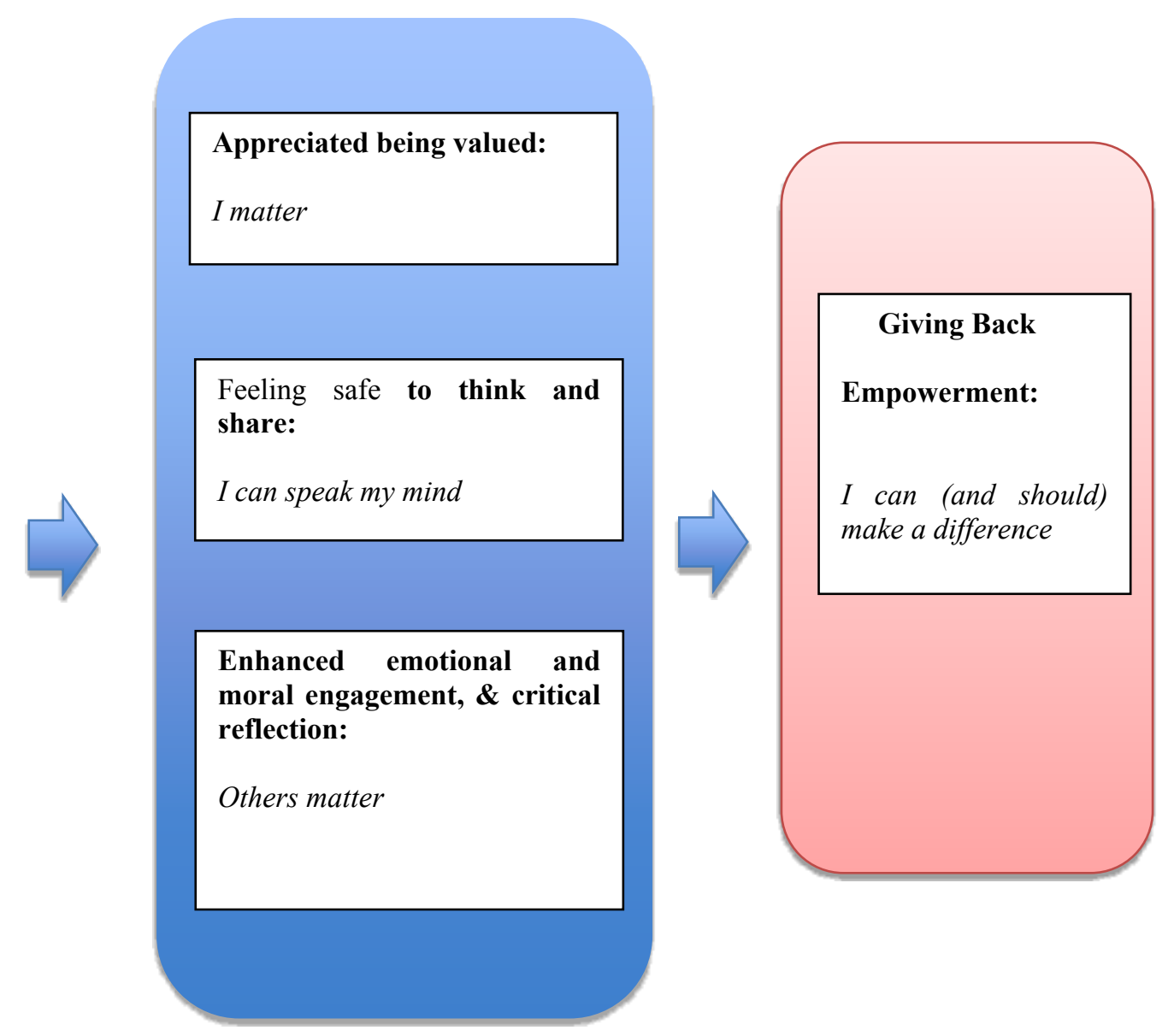




\title{
References
}

Abela A (2006) Marketing and consumerism: A response to O'Shaughnessy and O'Shaughnessy. European Journal of Marketing, 40(1/2): 5-16.

\author{
Alvesson M (1994) Critical theory and consumer marketing. Scandinavian Journal of \\ Management 10(3): 291-313.
}

Alvesson M and Willmott H (1992) On the idea of emancipation in management and organization studies. Academy of management review 17(3): 432-464.

\begin{abstract}
AMA (2013) American Marketing Association - Definition of Marketing. https://www.ama.org/AboutAMA/Pages/Definition-of-Marketing.aspx (accessed 30th April 2018)
\end{abstract}

Baden D and Higgs M (2015) Challenging the perceived wisdom of management theories and practice. Academy of Management Learning \& Education 14(4): 539-555.

Baker, M (2016) Marketing: Philosophy or Function?. In: Baker, M and Saren, M (eds) Marketing Theory - a Student Text. London: Sage Publications, pp. 3-30.

Barnett R (1997) Higher Education: A Critical Business. Maidenhead: McGraw-Hill Education.

Beirne M and Knight S (2007) From community theatre to critical management studies: A 
dramatic contribution to reflective learning? Management Learning 38(5): 591-611.

Bell E and Bridgman T (2017) Why management learning matters. Management Learning 48(1): 3-6.

Bergman JZ, Westerman JW and Daly JP (2010) Narcissism in management education. Academy of Management Learning \& Education 9(1): 119-131.

Bradshaw A and Tadajewski M (2011) Macromarketing roundtable commentary - the export of marketing education. Journal of Macromarketing 31(3): 312-321.

Brookfield S (1987) Developing Critical Thinkers - Challenging Adults to Explore Alternative Ways of Thinking and Acting. Milton Keynes: Open University Press.

Brookfield SD (1995) Becoming a Critically Reflective Teacher. San Francisco, CA: a Wiley Company.

Burton BK and Dunn CP (1996) Feminist ethics as moral grounding for stakeholder theory. Business Ethics Quarterly, 133-147.

Burton BK and Dunn CP (2005) The Caring Approach and Social Issues in Management Education. Journal of Management Education 29(3): 453-474.

Carroll L (1865/2009) Alice's Adventures in Wonderland and Through the Looking-Glass. Classic Books International. 
Catterall M, Maclaran P and Stevens L (2002) Critical reflection in the marketing curriculum. Journal of Marketing Education 24(3): 184-192.

Cornuel E and Hommel U (2012) Business Schools as a Positive Force for Fostering Societal Change: Meeting the Challenges of the Post-Crisis World. Business and Professional Ethics Journal 31(2): 289-312.

Crane A and Matten D (2016) Business Ethics. $4^{\text {th }}$ edition, Oxford: Oxford University Press.

Cunliffe AL (2002) Reflexive Dialogical Practice in Management Learning. Management Learning 33(1): 35-61.

Cunliffe AL (2004) On Becoming a Critically Reflexive Practitioner. Management Learning 28(4): 407-426.

Cunliffe, AL (2009) The philosopher Leader: On Relationalism, Ethics and Reflexivity-A Critical Perspective to Teaching Leadership. Management Learning 40(1): 87-101.

Davies R, Connolly K and Sample I (2017) Cladding for Grenfell Tower was Cheaper, more Flammable Option, The Guardian, https://www.theguardian.com/uknews/2017/jun/16/manufacturer-of-cladding-on-grenfell-tower-identified-as-omnis-exteriors (accessed $16^{\text {th }}$ June 2017)

Dehler GE, Welsh MA and Lewis MW (2001) Critical Pedagogy in the New 
Paradigm. Management Learning 32(4): 493-511.

Dehler GE (2009) Prospects and possibilities of critical management education: critical beings and a pedagogy of critical action. Management Learning 40(1): 31-49.

Eliot G (1955) The George Eliot Letters. In: Haight GS (Ed.). New Haven: Yale University Press.

Engster D (2011) Care Ethics and Stakeholder Theory. In: Hamington M and Sander-Staudt M (eds) Applying Care Ethics to Business. London: Springer, 93-110.

Fay B (1987) Critical Social Science. Cambridge: Pobty Press.

Fougère M, Solitander N and Young S (2014) Exploring and exposing values in management education: Problematizing final vocabularies in order to enhance moral imagination. Journal of Business Ethics 120(2): 175-187.

Fournier V and Grey C (2000) At the critical moment: Conditions and prospects for critical management studies. Human Relations 53(1): 7-32.

Gabriel Y (2009) Reconciling an ethic of care with critical management pedagogy. Management Learning 40(4): 379-385.

Giacalone R and Promislo M (2013) Broken when entering: the stigmatization of goodness and business ethics education. Academy of Management Learning \& Education 12(1): 86-101. 
Gilligan C (1982) In a Different Voice: Psychological Theory and Women's Development. Cambridge, MA: Harvard University Press.

Giroux HA (1981) Ideology, Culture, and the Process of Schooling. Philadelphia: Temple University Press.

Ghoshal S (2005) Bad management theories are destroying good management practices. Academy of Management learning \& education 4(1): 75-91.

Gössling T and Liedekerke L (2014) Editorial: the caring organisation. Journal of Business Ethics 120(4): 437-440.

Gray DE (2007) Facilitating management learning: Developing critical reflection through reflective tools. Management Learning 38(5): 495-517.

Hackley C (2003) ‘We Are All Customers Now...’ Rhetorical Strategy and Ideological Control in Marketing Management Texts. Journal of Management Strategy 40(5): 1325-1352.

Harris H (2008) Promoting ethical reflection in the teaching of business ethics. Business ethics: A European review 17(4): 379-390.

Hastorf AH and Cantril H (1954) They Saw a Game: a Case Study. Journal of Abnormal and Social Psychology 49(1): 129-134. 
Hawk TF (2011) An ethic of care: a relational ethic for the relational characteristics of organizations. In: Hamington M and Sander-Staudt M (eds) Applying Care Ethics to Business. London: Springer, 3-34.

Heath T, O’Malley L, Heath M and Story V (2016) Caring and conflicted: mothers' ethical judgments about consumption. Journal of Business Ethics 136(2): 237-250.

Held V (2006) The Ethics of Care: Personal, Political, and Global. Oxford: Oxford University Press.

Hendry J (2006) Educating managers for post-bureaucracy: the role of the humanities. Management Learning 37(3): 267-281.

Hudson LA and Ozanne JL (1988) Alternative Ways of Seeking Knowledge in Consumer Research. Journal of Consumer Research 14(4): 508-521.

Hühn, MP (2014) You reap what you sow: How MBA programs undermine ethics. Journal of Business Ethics 121(4): 527-541.

Kilbourne W and Carlson L (2008) The dominant social paradigm, consumption and environmental attitudes: can macromarketing education help? Journal of Macromarketing 28(2): 106-121.

Kilbourne WE, Dorsch MJ and Thyroff A (2017) Theorizing materialism through the Institutional Analysis and Development framework. Marketing Theory. 
Koehn D (2005) Transforming our Students: Teaching Business Ethics Post-Enron. Business Ethics Quarterly 15(1): 137-151.

Koehn D (2011) Care ethics and unintended consequences. In: Hamington M and SanderStaudt M (eds) Applying Care Ethics to Business. London: Springer, 141-153.

Kotler P (2011) Reinventing Marketing. Journal of Marketing 75 (4): 132-135.

Kurucz EC, Colbert BA and Marcus J (2014) Sustainability as a provocation to rethink management education: Building a progressive educative practice. Management Learning 45(4): 437-457.

Kvale S (1996) InterViews: An Introduction to Qualitative Research Interviewing. London: Sage.

Lawrence T and Maitlis S (2012) Care and possibility: enacting an ethic of care through narrative creation. Academy of Marketing Review 37(4): 641-663.

Liedtka JM (1996) Feminist morality and competitive reality: a role for an ethic of care? Business Ethics Quarterly 6(2): 179-200.

Machold S, Ahmed PK and Farquhar S (2008) Corporate governance and ethics: a feminist perspective. Journal of Business Ethics 81(3): 665-678. 
Nelson JA (2011) Care Ethics and Markets: a View from Feminist Economics In: Hamington M and Sander-Staudt M (eds) Applying Care Ethics to Business. London: Springer, 35-53.

Noddings N (1984) Caring: A Feminine Approach to Ethics and Moral Education. Los Angeles: University of California Press.

Noddings N (2002) Educating Moral People - A Caring Alternative to Character Education. New York: Teachers College.

Noddings N (2010) Moral education in an age of globalization. Educational Philosophy and Theory 42(4): 390-396.

Noddings N (2012) The caring relation in teaching. Oxford Review of Education 38(6): 771781.

Nonet G, Kassel K and Meijs L (2016) Understanding responsible management: Emerging themes and variations from European business school programs. Journal of Business Ethics 139(4): 717-736.

O’Malley L, Fowler E and Moore S (2016) Authenticity and transparency in the teaching of 'leadership readiness'. In: P. Buckley P, Daly E, Doyle and Reid K (eds) Innovative Business Education Design for 21st Century Learning. London: Springer.

O’Shaughnessy J and O'Shaughnessy NJ (2002) Marketing, the Consumer Society and Hedonism. European Journal of Marketing 36 (5/6): 524-547. 
Paillé P, Mejía-Morelos JH, Marché-Paillé A, Chen CC and Chen Y (2016) Corporate greening, exchange process among co-workers, and ethics of care: An empirical study on the determinants of pro-environmental behaviors at coworkers-level. Journal of Business Ethics 136(3): 655-673.

Palmer DE and Stoll ML (2011) Moving Toward a More Caring Stakeholder Theory: Global Business Ethics in Dialogue with the Feminist Ethics of Care. In: Hamington M and SanderStaudt M (eds) Applying Care Ethics to Business. London: Springer, 111-126.

Parker M (2018) Why we should Bulldoze the Business Schools. https://www.theguardian.com/news/2018/apr/27/bulldoze-the-business-school (accessed 28th April 2018)

Parker M and Jary D (1995) The McUniversity: Organization, management and academic subjectivity. Organization 2(2): 319-338.

Peattie K and Peattie S (2009) Social marketing: a pathway to consumption reduction. Journal of Business Research 62(2): 260-268.

Pratesi A (2011) The Productivity of Care: contextualizing care in situated interaction and shedding light on its latent purposes. Ethics and Social Welfare 5(2): 123-137.

PRME (2017) Principles for Responsible Management Education. Annual Review Regional Chapter, UK and Ireland. https://www.unprme.org.uk/single-post/2018/02/07/PRME-UK-and- 
Ireland-Annual-Review-2017 (accessed 10th of April 2018).

Reynolds M (1998) Reflection and Critical Reflection in Management Learning. Management Learning 29(2): 183-200.

Reynolds M (1999) Grasping the nettle: Possibilities and pitfalls of a critical management pedagogy. British Journal of management 10(2): 171-184.

Robinson F (2011) Stop talking and listen: Discourse ethics and feminist care ethics in international political theory. Millennium 39(3): 845-860.

Rubin HJ and Rubin IS (1995) Qualitative Interviewing: The Art of Hearing Data. London: Sage.

Ruddick S (1980) Maternal thinking. Feminist Studies 6(2): 342-367.

Samra-Fredericks, D (2003) A proposal for developing a critical pedagogy in management from researching organizational members' everyday practice. Management Learning, 34(3): 291-312.

Sander-Staudt M and Hamington M (2011) Introduction: care ethics and business ethics. In: Hamington M and Sander-Staudt M (eds) Applying Care Ethics to Business. London: Springer, vii-Xxii.

Schoemaker PJ (2008) The future challenges of business: rethinking management education. 
California Management Review 50(3): 119-139.

Simola S (2011) Elucidating the Role of Care in Ethical Decision-Making and action. In: Hamington M and Sander-Staudt M (eds) Applying Care Ethics to Business. London: Springer, 127-140.

Sinclair, A., 1997. The MBA through women's eyes: learning and pedagogy in management education. Management Learning 28(3): 313-330.

Śliwa, M, Sørensen BM, and Cairns G (2015) 'You have to choose a novel': The biopolitics of critical management education. Management Learning 46(3): 243-259.

Solomon MR, Zaichkowsky JL and Polegato R (1999) Consumer Behaviour: Buying, Having, and Being, Canadian Edition.

Spicer A, Alvesson M and Kärreman D (2009) Critical performativity: The unfinished business of critical management studies. Human relations 62(4): 537-560.

Starkey K and Tempest S (2009) The winter of our discontent: The design challenge for business schools. Academy of Management Learning \& Education 8(4): 576-586.

Starkey K and Tiratsoo N (2007) The Business School and the Bottom Line. Cambridge: Cambridge University Press.

Stoeckl VE and Luedicke MK (2014) Where marketing causes trouble. In: Varey RJ and Pirson 
M (eds) Humanistic Marketing. London: Palgrave Macmillan, 19-28.

Tadajewski M (2018) Critical Reflections on the Marketing Concept and Consumer Sovereignty. The Routledge Companion to Critical Marketing Studies. London: Routledge.

Tadajewski M and Brownlie D (2008) Critical Marketing: A Limit Attitude. In: Tadajewski M and Brownlie D (eds) Critical Marketing - Issues in Contemporary Marketing. West Sussex: John Wiley \& Sons Ltd, 1-7.

Taylor SJ and Bogdan R (1998) Introduction to Qualitative Research Methods: A Guidebook and Resource. New York: Wiley.

Thayer-Bacon B (2000) Transforming Critical Thinking. New York: Teachers College Press.

Thompson CJ (1995) A contextualist proposal for the conceptualization and study of marketing ethics. Journal of Public Policy \& Marketing 14(2): 177-191.

Thompson CJ (1996). Caring consumers: Gendered consumption meanings and the juggling lifestyle. Journal of Consumer Research 22(4): 388-407.

Timmons, M (2002) Moral Theory. Oxford: Rowman \& Littlefield Publishers, Inc.

Tronto JC (1987) Beyond gender difference to a theory of care. Signs 12(4): 644-663.

Tronto JC (1995) Care as a Basis for Radical Political Judgments. Hypatia 10(2): 141-149. 
Varey RJ (2010) Marketing means and ends for a sustainable society: a welfare agenda for transformative change. Journal of Macromarketing 30(2): 112-126.

Vince R (2010) Anxiety, politics and critical management education. British Journal of Management 21: 26-39.

Wallace M and Wray A (2011) Critical Reading and Writing for Postgraduates. London: Sage.

Wicks AC, Gilbert Jr DR and Freeman RE (1994) A feminist reinterpretation of the stakeholder concept. Business ethics quarterly: 475-497. 